\title{
Выводы
}

Внедрение компетентностного подхода в высшее образование России пока носит формальный характер, что не позволяет реализовать все возможности этого перспективного подхода. Для его содержательного внедрения потребуется пересмотреть сложившуюся практику формирования рабочих учебных планов, рабочих программ дисциплин и других учебно-методических документов, подчинив их единой цели: непрерывному формированию системы требуемых компетенций на протяжении всего периода обучения. Методической основой такого формирования должна стать модель непрерывного развития компетенций.

$$
* * *
$$

1. ГОСТ Р ИСО 9000-2015 Системы менеджмента качества.

2. Федеральный государственный образовательный стандарт высшего образования уровень высшего образования бакалавриат направление подготовки 38.03 .03 «Управление персоналом».

3. Алексенцева О.Н., Демина А.В. Использование облачных технологий в информационной системе СГСЭУ. // «Информационно-коммуникационные технологии в сфере культуры и образования» сб. науч. тр. по итогам Межд. науч.-методич. конф.» (г. Саратов 8-10 апреля 2014г.) / под общей редакцией Г.А Суминой / СГСЭУ. - Саратов, 2014. $-118 \mathrm{c}$.

4. Алексенцева О.Н., Демина А.В. Использование сетевого планирования для организации учебного процесса // Вестник Саратовского государственного социально-экономического университета. 2017. № 1 (65). C. $16-18$

5. Безруков А.И., Алексенцева О.Н.. Математическое и имитационное моделирование: учеб.пособие - М : ИНФРА_М, $2017227 \mathrm{c}$.

6. Гусятников В.Н., Безруков А.И. Стандартизация и разработка программных систем: учеб.пособие - М: Финансы и статистика; ИНФРА_М, 2010 -288 с: ил.

7. Гусятников В.Н., Безруков А.И.,, Каюкова И.В. Математические модели для анализа процессов формирования компетенций. Математические методы в технике и технологиях - ММТТ. 2014. Т. 7. № 7-1 (66). C. 82-85.

8. Гусятников В.Н., Безруков А.И., Соколова Т.Н. Проблемы формирования компетенций в области информационной безопасности. Информационная безопасность регионов. 2014. № 2. С. 27-31.

9. Демина А.В. Концепция курса// Вестник Тамбовского университета. Серия: Гуманитарные науки. 2008. № 9 (65). С. 205-207

10. Демина А.В., Преображенская Е.В. Параметрическая модель подготовки бакалавров направления «Бизнес информатика »//Информационная безопасность регионов. 2015. № 1 (18). С. 5-10.

11. Дёмина А.В., ПчелинцеваЕ.Г.Методика вычисления фальшивых аккаунтов в социальных сетях // Информационная безопасность регионов. 2015. № 3 (20). С. 16-19.

12. Егоров Е.Е., Анисенко А.В., Бурлакова Ю.В., Быкова Н.С. Проектная деятельность как инновационная технология в системе современных подходов к обучению. Мир науки. 2016. Т. 4. № 4. С. 12.

13. Махонин Д.А. Проектный подход к технологии обучения в системе высшего профессионального образования. Качество инновации образование №1, 2005. С.11-21

\section{Бекмаганбетова Г.К. \\ Критерии и показатели сформированности у младших школьников семейных ценностей}

«Национальный цеентр повышения квалификации «Өрлеу» Институт повымения квалификаџии педагогических работников по Костанайской области» (Республика Казахстан)

doi:10.18411/lj-31-03-2018-41

idsp: 000001:lj-31-03-2018-41

\section{Аннотация}

В статье рассматриваются вопросы апробации комплекса проектов взаимодействия семьи и школы по формированию у младших школьников семейных ценностей. Раскрываются понятия педагогической диагностики, как изучение состояния 
педагогического процесса и выработка ряда критериев и показателей для оценки успешности по формированию у младших школьников семейных ценностей.

Ключевые слова: семейные ценности, диагностика, критерии и показатели, духовность и нравственность, младший школьник.

Рассматривая понятие «диагностика», мы обращаемся к определению В. Б. Моисеева, согласно которому, «диагностика - это процедура выявления уровня готовности к какому-либо виду деятельности, в том числе к учебной деятельности определенного содержания и уровня сложности. В более узком употреблении термин обозначает процедуру и совокупность способов проверки успешности освоения учебного материала» [1].

В свою очередь, диагностика педагогическая - это «изучение состояния педагогического процесса». Согласно Российской педагогической энциклопедии, педагогическая диагностика представляет собой «совокупность приемов контроля и оценки, направленных на решение задач оптимизации учебного процесса, дифференциации учащихся, а также совершенствования учебных программ и методов педагогического воздействия». Педагогическая диагностика - неотъемлемый компонент педагогической деятельности, т. к. осуществление процессов обучения и воспитания с необходимостью требует оценки, анализа и учета результатов этих процессов. Усвоение обучающимися учебного материала непосредственно зависит от наличного уровня их познавательного и личностного развития. Оно также определяется мерой сформированности умственной деятельности учащихся, степенью освоения ранее преподанных знаний, умений, навыков. Отсутствие учета этих факторов вызывает затруднения в процессе освоения новой информации, новых приемов познавательной деятельности, их согласования с теми, которые должны были быть освоены ранее [2].

Развитие - «направленное, закономерное изменение; в результате развития возникает новое качественное состояние объекта - его состава или структуры» [3].

Диагностика результатов личностного развития младших школьников в настоящий момент активно обсуждается педагогами, методистами, психологами, исследователями педагогической практики. Нравственное развитие является неотъемлемой, составляющей частью личностного развития младшего школьника. Учитывая тот факт, что духовное и нравственное воспитание становиться обязательным условием реализации Федеральных государственных образовательных стандартов начального общего образования, изучение нравственного развития, ценностных отношений младших школьников становится наиболее актуальным [4].

Необходимо рассмотреть основные понятия, используемые в данной главе, такие как: «диагностика», «педагогическая диагностика», «критерий» и «показатель», «развитие».

Рассматривая понятие «диагностика», мы обращаемся к определению В. Б. Моисеева, согласно которому, «диагностика - это процедура выявления уровня готовности к какому-либо виду деятельности, в том числе к учебной деятельности определенного содержания и уровня сложности. В более узком употреблении термин обозначает процедуру и совокупность способов проверки успешности освоения учебного материала» [1].

В свою очередь, диагностика педагогическая - это «изучение состояния педагогического процесса». Согласно Российской педагогической энциклопедии, педагогическая диагностика представляет собой «совокупность приемов контроля и 
оценки, направленных на решение задач оптимизации учебного процесса, дифференциации учащихся, а также совершенствования учебных программ и методов педагогического воздействия». Педагогическая диагностика - неотъемлемый компонент педагогической деятельности, т. к. осуществление процессов обучения и воспитания с необходимостью требует оценки, анализа и учета результатов этих процессов. Усвоение обучающимися учебного материала непосредственно зависит от наличного уровня их познавательного и личностного развития. Оно также определяется мерой сформированности умственной деятельности учащихся, степенью освоения ранее преподанных знаний, умений, навыков. [5].

«Развитие - направленное, закономерное изменение; в результате развития возникает новое качественное состояние объекта - его состава или структуры» [6].

Таким образом, под диагностикой духовно-нравственного развития подразумевается совокупность способов и приемов оценки изменений уровня развития духовности и нравственности в процессе использования КТД.

Для того, чтобы оценить успешность взаимодействия семьи и школы по формированию у младших школьников семейных ценностей необходимо провести диагностику, необходимо выработать ряд критериев и показателей. Под критерием мы понимаем «признак, на основании которого производится оценка, определение или классификация чего-либо». Признак, в свою очередь, определяется как «свойство, по которому познают или узнают предмет; определения, которые отличают одно понятие от другого».

Показатель - это любая характеристика объекта восприятия, исследования, которая может быть оценена человеком.

Об особенностях сформированности нравственных ценностей школьников можно судить на основании таких основных критериев, как когнитивный, эмоциональный, поведенческий. (А.Г. Адамова, Г.П. Иванова, М.В. Куранова, Е.В. Михайлова, М.В. Новоходская) [4].

Когнитивный (интеллектуально-волевой, когнитивно-познавательный) критерий характеризуется следующими показателями - полнота и объем нравственных знаний и знаний о ценностях, ценностное отношение к познанию, нравственная мотивация в деятельности, ценностное отношение к близким людям, творческое отношение к задачам, замыслам, поручениям. Для изучения данного критерия можно использовать диагностическую методику оценки уровня нравственного развития и воспитания младших школьников (субъективный тест классного руководителя, предложенный М.И. Шиловой).

Показателями эмоционального (эмоционально-ценностного, эмоциональноволевого, эмоционально-мотивационного) критерия являются: степень развития эмоционального к нравственно значимым ценностям, ценностное отношение к семье, способность к рефлексии, способность к интерпретации понятий. Для изучения данного критерия можно использовать диагностическую методику - анкета «Я и моя семья диагностика семейных ценностей и представлений учеников; Цель: уровень сформированности семейной культуры.

Поведенческий (коммуникативный) критерий характеризуется такими показателями, как: наличие практического опыта следования принятым нравственным ценностям в поведении; способностью оценивать свое поведение и окружающих с позиции следования нравственным ценностям (наличие собственных оценочных суждений; сформированностью способности коммуникации на основе ценностных 
ориентаций. Для изучения данного критерия можно использовать метод диагностики беседа. При использовании беседы по сюжетному рассказу учащимся предлагалось прослушать рассказ «Сыновья» В. Осеевой, содержащий нравственную проблему.

На основании выделенных критериев и показателей диагностики можно выделить уровни сформированности у младших школьников семейных ценностей.

Для низкого уровня сформированности у младших школьников семейных ценностей характерны: несформированность нравственных понятий, неустойчивое, импульсивное поведение; несоответствие представлений о нравственно-волевых качествах возрасту; отсутствие нравственной мотивации; неадекватные эмоциональные реакции; неадекватность рефлексивной самооценки учебной деятельности; преобладание атрибуции везения; отсутствие способности к интерпретации высказываний; отсутствие ориентации на подлинные жизненные ценности; низкий уровень освоения уровня справедливого распределения, осознания нормы, моральных суждений; неумение выделить мотив, обстоятельства и объективные последствия поступка; отсутствие навыков совместного сотрудничества.

Для удовлетворительного уровня сформированности у младших школьников семейных ценностей характерны: эгоистическая позиция; неточность в определении содержания положительных и отрицательных качеств личности; нестабильность нравственной мотивации; адекватные, но слабовыраженные эмоциональные реакции; нечеткость рефлексивной самооценки учебной деятельности; ориентация на атрибуции способности и объективная сложность; стремление за словами увидеть ценностное отношение; нечеткая ориентация на подлинные жизненные ценности; средний уровень освоения уровня справедливого распределения, осознания нормы, моральных суждений; неточность выделения мотива, обстоятельств и объективных последствий поступка; ориентация на коммуникацию в общем деле.

Высокий уровень сформированности у младших школьников семейных ценностей характеризуется устойчивая ориентация на положительное поведение; сформированность представлений о духовных и нравственных ценностях согласно младшему школьному возрасту, сформированность нравственной мотивации; адекватные эмоционально яркие эмоции; адекватность рефлексивной самооценки учебной деятельности; атрибуция на собственные усилия; видение ценностного отношения в высказываниях; ориентация на жизненные ценности; высокий уровень освоения уровня справедливого распределения, осознания нормы, моральных суждений; ориентация на мотив, обстоятельства и объективные последствия поступка; активная позиция и стремление к продуктивному сотрудничеству.

Итак, мы обосновали критерии и показатели сформированности у младших школьников семейных ценностей. Об особенностях сформированности семейных ценностей школьников можно судить на основании таких основных критериев, как когнитивный, эмоциональный, поведенческий. Когнитивный критерий характеризуется следующими показателями: полнота и объем нравственных знаний и знаний о ценностях, ценностное отношение к познанию, нравственная мотивация в деятельности, ценностное отношение к близким людям, творческое отношение к задачам, замыслам, поручениям. Показателями эмоционального (эмоционально-ценностного, эмоционально-волевого, эмоционально-мотивационного) критерия являются: степень развития эмоционального к нравственно значимым ценностям, ценностное отношение к семье, способность к рефлексии, способность к интерпретации понятий. Поведенческий (коммуникативный) критерий характеризуется такими показателями, как: наличие практического опыта 
следования принятым нравственным ценностям в поведении; способностью оценивать свое поведение и окружающих с позиции следования нравственным ценностям (наличие собственных оценочных суждений; сформированностью способности коммуникации на основе ценностных ориентаций. На основании выделенных критериев и показателей диагностики можно выделить уровни сформированности у младших школьников семейных ценностей: низкий, удовлетворительный, высокий.

$$
\text { *** }
$$

1. Давыдова, О. Семейные проекты / О. Давыдова. - М. Кизил // Обруч. - 2004. - № 2. - С.25-28.

2. Крыгина, Н. Н. Основы психологии пола: Учеб.пособие для студентов ун-тов / Н. Н. Крыгина. Магнитогорск: МаГУ, 2003. - 110 с.

3. Кобахия, Е. Е. Проектный метод в системах образовательной работы / Е. Е. Кобахия // Педагогическая диагностика. - 2009. - №.4. - С.26-38.

4. Коган, М. С. Воспитательная работа: дети - учителя - родители: Методическое пособие / М. С. Коган. Новосибирск, 1999. - 54 с.

5. Духовно-нравственные основы семьи: Хрестоматия для учителя. Ч 1, 2, 3 / Сост. Т. Г. Кислицына. 2-е изд. - М.: Школьная пресса, 2001.

6. Андреев, Г. П. К столетию метода проектов / Г. П.Андреев [и др.] // Школьные технологии. - 2005. - № 4. - C. $28-30$.

\section{Дильдибекова Г.А.}

\section{Духовно-нравственное воспитание подростков: сущность, структура и функции}

Национальный Центр Повышения Квалификации «Өрлеу» ИПК ПР по Костанайской области (Республика Казахстан, Костанай)

doi:10.18411/lj-31-03-2018-42

idsp: 000001:lj-31-03-2018-42

\section{Аннотация}

Рассматриваются вопросы духовно-нравственного воспитания школьника России, представляющие процесс организованного, целенаправленного внешнего и внутреннего воздействия педагога на духовно-нравственную сферу личности, являющуюся системообразующей внутреннего мира школьника. Раскрываются вопросы сущности, структуры и функции духовно-нравственного воспитания школьников, как педагогической деятельности направленной на создание условий успешного развития детей.

Ключевые слова: духовность и нравственность, личность, школьник, воспитание, сущность, структура, функции

Педагогика занимает особое место среди гуманитарных наук, являясь наукой о воспитании человека. Рассмотрев ряд подходов к духовно-нравственному воспитанию, следует отметить сущностную характеристику «духовности» и «нравственности», связанных мотивационной сферой, внешние проявления это (нравственность) и внутреннее (духовность). Между духовностью и нравственностью существует, несомненно, существует глубокая связь. [1, с. 619-622.]

Духовно-нравственное воспитание - один из аспектов воспитания, направленный на усвоение подрастающими поколениями и претворение в практическое действие и поведение высших духовных ценностей.

По словам учёного В. И. Павлова, духовно-нравственное воспитание личности направлено на формирования её: нравственных чувств - совести, долга, веры, ответственности, гражданственности, патриотизма; нравственного облика - терпения, милосердия, кротости, незлобивости; нравственной позиции - способности к различению 